\title{
Free and Unfree Labour in the Colonial Andes in the Sixteenth and Seventeenth Centuries
}

\author{
Raquel Gil Montero \\ Instituto Superior de Estudios Sociales (CONICET-UNT), \\ Tucumán \\ E-mail: raquelgilmontero@gmail.com
}

SUMmARY: This article analyses free and unfree labour in mining centres in the Andes during early Spanish colonial times. It focuses on two themes: the condition of indigenous or "native" people as "free labourers", and the mita system of unfree labour. For that purpose I shall consider the cases of Potosí, the most important mining centre in the Andes, and San Antonio del Nuevo Mundo in southern Bolivia, a large mine unaffected by the mita system of labour obligations.

In 1977 I observed a ceremony during the San Bartolomé fiesta (24 August) when people remembered how the mitayos had joined the day after going to Potosí. One mounted "mitayo" brought "documents" in his hat, and the people told me that they were remembering how their ancestors had gone away to earn the rights to their land, "eating earth in the processing mills" of Potosí.

The conquest of the Americas coincided with a period of European demographic expansion and changes in the technology of warfare that demanded - among other things - an increase in the production of metals. ${ }^{2}$ Mining was one of the most important activities in the New World, and it began, as did the history of indigenous labour in the Andes, almost immediately after the arrival of the Spaniards and their conquests in the early i 5305 , when they started to exploit old mining centres belonging to the former rulers, the Incas, and to look for new ones.

In the Andes, the indigenous populations were the principal labour force because of their numbers and because silver mining, the most significant economic activity in the region during colonial times, took place in

I. Tristan Platt, "Tributo y ciudadanía en Potosí, Bolivia. Consentimiento y libertad entre los ayllus de la Provincia de Porco, 1830-1840”, Anuario de Estudios Bolivianos, Archivísticos y Bibliográficos, I 2 (2008), pp. 33 I-395, 385 , n. 57 (my translation).

2. Hans-Joachim Kraschewski, Betriebsablauf und Arbeitsverfassung des Goslarer Bergbaus am Rammelsberg vom I6. bis zum I8. Jabrbundert (Bochum, 2002), pp. I3-I4; Julio Sánchez Gómez, De minería, metalúrgica y comercio de metales, 2 vols (Salamanca, I989), I, p. 9 I. 
the arid upland territories they inhabited. Silver mining required a complex organization, and supplies of food, wood, salt, clothes, and other goods had to be brought in over vast distances. Some old traditional mines such as Porco or Carabaya were surrendered to the Spaniards in the early years; others were kept secret, at a time considered by many historians as turbulent and violent.

The principal event that changed the history of mining in the Andes in colonial times was the "discovery" of Potosí in I545. During its silver boom, Potosí accounted for 90 per cent of the silver output of the Peruvian Viceroyalty. ${ }^{3}$ Three steps were important in making Potosí such a centre: the organization of labour, improvements in technology, and the supply of mercury.

The main coordinator of the mining system was Francisco de Toledo (I5I5-I582), the Viceroy of Peru from I569 to I58I. In order to provide a stable allocation of labour for the mines every year, he created the so-called mita system. The Potosí mita was a state-coordinated form of draft labour, organized in the I570s, whereby communities belonging to sixteen provinces throughout the region were obliged to send a designated number of workers (men aged between eighteen and fifty) to work for specific mining concerns. The mita system was originally devised by the Incas, but the Spanish, particularly under Viceroy Francisco de Toledo in the I570s, adapted and expanded it to serve the needs of the mining economy. There were also other mitas, not concerned with mining, but they were less important than the system under discussion here. ${ }^{4}$

Mines in the Andes were located mostly in territories where mining activity had been present before the Spaniards came and where there were significant populations, important differences from the case of most of the mines in Mexico, which was the other important mining centre during colonial times. ${ }^{5}$ The Spanish, however, considered the high regions to be isolated deserts, mostly because of the absence of trees and agriculture. In I 85 , Capoche wrote about Potosí: "It is situated in cold, snow-covered, sterile, fruitless and almost uninhabitable high lands. Because of its bad temperament [i.e. climate] $[\ldots]$ no sustenance grows there but some potatoes."

3. Enrique Tandeter, "Los ciclos de la minería de metales preciosos: Hispanoamérica", in idem and Jorge Hidalgo Lehuedé (eds), Historia general de América Latina, IV: Procesos americanos bacia la redefinición colonial (Madrid, 2000), pp. I27-148.

4. The three most important books on the Potosí mita, which explain its characteristics and evolution, are Peter Bakewell, Miners of the Red Mountain: Indian Labour in Potosi, I 545-1650 (Albuquerque, NM, 1984); Jeffrey A. Cole, The Potosi Mita, 1573-I700: Compulsory Indian Labor in the Andes (Stanford, CA, 1985); and Enrique Tandeter, Coacción y mercado. La minería de la plata en el Potosi colonial, 1692-I826 (Buenos Aires, 1992).

5. Peter Bakewell, Minería y sociedad en el México colonial. Zacatecas (I546-I700) (Mexico City, 1976); Carmen Salazar-Soler, “'Quilcar los indios’: a propósito del vocabulario minero andino de los siglos XVI y XVII”, in Ana María Lorandi et al. (eds), Los Andes, cincuenta años después (1953-2003). Homenaje a John Murra (Lima, 2003), pp. 28 I-3 I 5.

6. Luis Capoche, Relación general de la Villa Imperial de Potosi [Biblioteca de Autores Españoles] (Madrid, I959 [1585]), p. 75 (my translation). 
Potosí grew rapidly as a result of mining and other commercial activities. The majority of its population were indigenous people who worked in the mines and processing mills, although, in spite of the importance of the mita system, the majority of the indigenous inhabitants were, if we can believe the sources, "free wage labourers". All indigenous men aged between eighteen and fifty had to pay tribute as vassals, sometimes to the Crown, sometimes to an individual Spaniard. What they paid as tribute changed over time, and the total amount included not only money, but also labour and goods.

Some communities too were obliged by Viceroy Toledo to adopt mita as a system of forced labour to help fund the initial investments in the new amalgam technology. Some Indians went to the mines to fulfil their mita obligation by working there, and their wages were assessed at a figure below market value, but others went there as free labourers. Most tribute was valued in silver or money, and therefore working in the mines at market-rate wages to earn the money to pay the tribute was more advantageous than rendering the service directly in the form of labour.

Because of the mita system, forced labour in Potosí was, and is, at the centre of the discussion among historians about mining activity in the Andes, and mita has been considered the worst example of forced labour ever since the struggle for independence. However, in a recent article, Tristan Platt qualified it as a system of "voluntary unfree labour". Although mitayos were obliged to go to mining sites, some historians, including Platt, argue that the natives had an opportunity to negotiate because the Spaniards required the approval of the local native authorities. Platt adds that fulfilling the terms of mita meant receiving benefits, in a kind of reciprocity pact between the Spanish and the natives. In the epigraph to his article, Platt describes a contemporary representation of the "colonial pact" that existed in what is now northern Potosí, a reference to the past origins of the institution of the mita system. In many of his studies Platt stresses the fact that the indigenous people had a changing capacity for making deals based on their autonomy and relative power, even in the most coercive colonial situations. Tandeter found other examples of the "colonial pact" from the beginning of the nineteenth century in Oruro (see Figure I). ${ }^{7}$

\section{COLONIAL MINING AND POPULATION IN MODERN-DAY BOLIVIA}

Throughout the early colonial period it was the mining economy that fuelled population growth in territories regarded by the Spanish as infertile and dry. Such growth was possible because of large-scale immigration to mining 


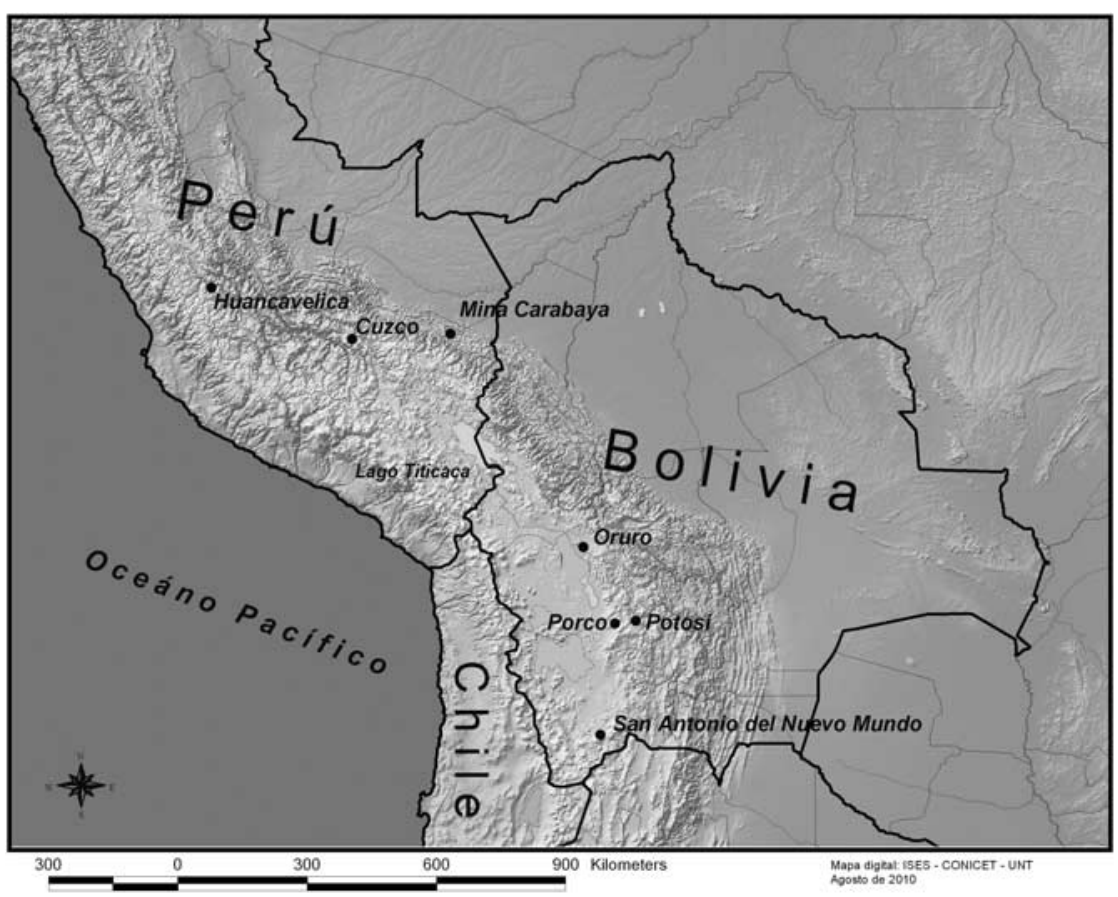

Figure I. Andes cities and mines during the seventeenth century.

Natural Earth (www.naturalearthdata.com), August 2010

centres by labourers from all corners of the Peruvian viceroyalty. The labouring population needed to be fed and kept supplied, and the people who brought the provisions - often from very distant places - also added to the population. In his Natural and Moral History of the Indies, Father Acosta noted:

In very harsh lands, dry, and infertile, with very high mountains, sharp crevasses, and very inhospitable, gold and mercury mines were established, and there also took place the washing and processing of gold. All this wealth was destined to go to Spain. After the discovery of the West Indies, other similar harsh, laborious, infertile, and barren places were occupied for such purposes. It was the love of money that made such places liveable, rich, and populous. ${ }^{8}$

In Bolivia today, this dry highland is called the altiplano and was conquered by the Incas before the Spaniards went there. In I 535 a small group of Spaniards, followed by some native authorities (Incas and other ethnic groups), together with many indigenous warriors, crossed the

8. José Acosta, Historia Natural y moral de las indias (Mexico City, 2006 [I589]), p. I6I (my translation). 
highlands in the direction of Chile. The traditional historiography relates that everything was accomplished by only a small group of Spaniards. Everything about them is recorded: their names, numbers, weapons, and what finally became of them. In recent years, however, the role of indigenous allies and authorities has been emphasized more and more, and so have their different strategies. Diego de Almagro, for example, went to Chile with very important Inca authorities. They mobilized thousands of warriors, and on their way south concluded peace agreements with other authorities. The locals were also able to reveal, or not to reveal, to the Spaniards the sites of mines and other riches. ${ }^{9}$

The name of the province Almagro crossed was Charcas, the major part of what is now Bolivia and the most important mining district during Inca and pre-Inca times, but his group turned south, not knowing that they were leaving such wealth behind. It was not until i 538 that Paullu Inca and a number of other indigenous authorities decided to reveal to the Spaniards the Inca mine in Porco (see Figure I). ${ }^{\circ}$

Potosí on the other hand was "discovered" only in i 545 . The official Spanish history tells that it was a desert and that the find was made by Diego Guallpa, a "servant". He lost a llama and had to stay overnight in Potosí, where he happened upon the silver quite by chance. ${ }^{\text {II }}$ Recent studies show that the location was known to the Incas and to the pre-Inca population and that the region was inhabited. By September i 545 there were I70 Spaniards and 3,000 Indians settled at the foot of the Potosí mountain, writes Cook. ${ }^{\mathrm{I2}}$ Within just two years, there were around 2,500 houses and I 4,000 inhabitants. In the beginning, the exploitation of the mines was based on native technology, but adapted to the colonial scale of production. The refining process, too, was carried out using native practices, with wind furnaces (buayras) placed at the top of the mountain.

As already mentioned, the early colonial years were turbulent: the Spanish arrived in the midst of a civil war between two Inca descendants vying with one another to rule the empire and started a merciless war of conquest which was itself followed by a Spanish civil war. There is an important and still ongoing discussion about the demographic transformation

9. Medinaceli Ximena and Arze Silvia, "Los mallkus de Charkas. Redes de poder en el norte de Potosí (siglos XVI y XVII)”, Estudios Bolivianos, 2 (1996), pp. 283-319.

ı. Tristan Platt and Pablo Quisbert, "Tras las huellas del silencio. Potosí, los Incas y el Virrey Toledo", Anuario de Estudios Bolivianos, Archivisticos y Bibliográficos, I 2 (2008), pp. 389-428. I I. There are at least two versions of the discovery, and the bibliography is very large. See, for example, Julio Lucas Jaimes, La Villa imperial de Potosi, su historia anecdótica, sus tradiciones y leyendas fantásticas. Su grandeza y opulencia fabulosas (Buenos Aires, 1905), pp. I-6; and Pedro Vicente Cañete, Historia Física y Política de la Provincia de Potosí, with an introduction and notes by Gunnar Mendoza (La Paz, I952 [1797]), I, pp. 49-5 I.

I2. Noble David Cook, Demographic Collapse: Indian Peru, I520-1620 (Cambridge, I981), p. 236. 
in the Andes, referring to factors such as civil war, violence, conquest, and epidemics. ${ }^{13}$ Although information is scarce for the first few decades, specialists agree on the rhythm of the dramatic decrease in population.

The Spaniards began their domination in Cuzco - the Inca's capital city where they settled in I535, and two years later they moved to Lima. In the I 540 s they organized the first royal inspection (visita) in order to collect information about the Andean population and resources; such inspections were repeated from time to time. Based on those sources, scholars believe that the worst period of the demographic downturn was after the Toledo reforms of the late I570s. ${ }^{I 4}$ In spite of the devastating effects of the wars and epidemics, the most important factors affecting the native population seem to have been the forced recruitment of labour and the organization of indigenous villages, called repartimientos. The latter were new towns where the native population were forced to live, established in order to control, indoctrinate, and tax them more efficiently. According to Cook, the first "universal plague" arrived in Cuzco in 1585 (measles and smallpox). ${ }^{15}$ The forced concentration and migration favoured the spread of such epidemics.

What happened in Charcas is important for the discussion of the demographic decline because Potosí, the main gathering place for all migrants, lay in that province. The recorded diminution of the tribute-paying population does not mean that the native population necessarily shrank at the same pace, as was assumed by earlier research. During the reforms implemented by Viceroy Toledo, many tributaries (in the Latin American historiography, tributaries were indigenous people obliged to pay tribute) began to migrate and their tributary status changed. Another fundamental process for the history of the Americas, the mixing of ethnic groups in the so-called mestizaje, started at the same time. Of course, such new considerations do not mean that demographic decline did not take place. What is at the centre of the discussion nowadays is its intensity and geographical setting.

Summing up the main facts affecting the native population in what is now Bolivia, we should mention migration, a significant increase in mortality rates, changes in tributary status, urbanization around mining

I 3. Ibid., p. 247, speaks about collapse as a process taking place along the Pacific desert strip and in the low-lying areas of the northern highlands; according to him, the highlands proper experienced a less pronounced downward spiral.

I4. Franklin Pease and Frank Moya Pons (eds), Historia General de América Latina, II: El primer contacto y la formación de nuevas sociedades, p. I62. This is not, however, the opinion of other scholars, such as Assadourian. See Carlos Sempat Assadourian, “'La gran vejación y destruición de la tierra’: las guerras de sucesión y conquista en el derrumbe de la población indígena del Perú", in idem, Transiciones hacia el sistema colonial andino (Lima, 1994), pp. 19-62.

I s. Noble David Cook, "Epidemias y dinámica demográfica", in Pease and Moya Pons, El primer contacto, pp. 30I-3 I 8. 
centres, and the mixing of ethnic groups. The principal causes of all of that can be found in the organization of tribute and labour.

\section{COLONIAL TRIBUTES AND LABOUR}

Tribute received from indigenous people were considered to be "personal tribute" payable by all "free vassals" of the Crown of Castile, men between the ages of eighteen and fifty. ${ }^{16}$ At first, the Crown ceded the right to collect this tribute to a number of individual Spaniards, the socalled encomenderos, in recompense for their services. The Spanish obliged Indians to pay them in goods, silver, or personal services.

Did tribute exist during pre-Hispanic times? John Murra - probably the best-known specialist in central Andean history - believes that it did not. According to him, people owed the Incas principally "energy" for work and only some "crude" goods, in the sense meant by Claude Lévi-Strauss, that is: honey, feathers, fish, and eggs gathered from wild birds. ${ }^{17}$ In the early royal inspections, however, the natives asserted that they gave the Incas "crude" and also "processed" goods, including textiles, llamas, and wool, and, most importantly, that they provided labour for agriculture, mining, warfare, and herding; they might also provide persons, women, servants, and local individuals for sacrifice. The Incas assumed the power to demand such services, and the Spanish too later began to ask for labour in line with their own needs, namely for cultivation, transport, and working in the mines. There was continuity with the Inca system, but some data suggest that the Spanish asked for a wider range of goods as well, and almost all testimonies agree that there was practically no limit to their demands.

Under the rule of Viceroy Pedro de la Gasca (I546-I 550 ), the colonial authorities began to regulate the tribute imposed on the natives. It is interesting to note that, in many cases during that period of government, tribute was the result of negotiation, because tribute is stable and profitable only if tributaries are able to pay it. As far as we know from Spanish texts, the native inhabitants told the authorities that they had not been consulted during the inspection carried out by the Spanish official, Ortiz de Zúñiga. ${ }^{{ }^{8}}$ Some of the indigenous authorities claimed that "they were visited and counted and the tributes valued, but without their opinion or

16. Ronald Escobedo Mansilla, El tributo indigena en el Perú (siglos XVI-XVII) (Pamplona, I979), p. 22. In some periods and regions, all married men or men between the age of fifteen and fifty were liable.

17. John Murra, “¿Existieron el tributo y los mercados en los Andes antes de la invasión europea?", in idem, El mundo andino. Población, medio ambiente y economía (Lima, 2002), pp. 237-247. "Crude" products were natural products usually gathered by young people. Murra also proposed that there were different norms that ruled natural and processed goods.

18. Carlos Sempat Assadourian, "La renta de la encomienda en la década de I550: piedad cristiana y desconstrucción”, in idem, Transiciones hacia el sistema colonial andino, pp. I 7 I-208. 
approval having been requested". ${ }^{19}$ The complaints also stressed the difference between paying in labour and paying in goods, demanding that the latter be reduced.

One can see a transition from one kind of payment to the other and, in the second category, a shift to payments of money, which obliged the locals to work to obtain the money to fulfil their obligations. Moreover, such protests show that the indigenous people expected that they should have the option to negotiate, and that they resented having their bargaining position weakened. According to the value of the tribute assigned by La Gasca, the natives of the Andes had to pay the highest rate in the Spanish overseas territories, amounting to 5-6 pesos, while in New Spain (Mexico) the natives paid the equivalent of 2 silver pesos, and in the Philippines less than I peso.

In his negotiations with private Spanish entrepreneurs, La Gasca was unable to discuss the mining labour organized by the first generation of entrepreneurs, ${ }^{20}$ for his mission was to reconcile the needs of private mining speculators with those of the Crown, rather than to protect the indigenous population. The native people of Charcas wanted to contribute using silver and not other goods, and they wanted to go to Potosí to work in the mines there, rather than in "mines" in general. In the early days of Potosí, where processing was dependent on native furnaces, the indigenous people had some degree of control over silver production and could earn more money.

A royal inspection organized a few years after this first assessment and before the introduction of the mita system allows us to describe the labour provided by the native people for the conquerors. The natives living in Chucuito, the Lupaqa, were in a singular position within the Peruvian context because they were one of the few groups who managed to pay tribute directly to the Crown and not to Spanish individuals (the encomenderos). The witnesses interviewed for the royal inspection affirmed that under the Incas, who had conquered them some years before the Spaniards came, the Lupaqa had to provide tribute in the form of men for military service, women as concubines and mistresses, boys and girls for sacrifice, artisans to work in Cuzco, a workforce for the gold and silver mines, tribute in the form of clothes and food (such as potatoes, quinua grain, and llamas), "crude" goods such as feathers and fish, as well as to maintain local places of refuge, where travellers could obtain food, shelter, and rest for themselves and their animals. ${ }^{21}$

19. Iñigo Ortiz de Zúñiga, Visita de la provincia de Huánuco en Is62 (Lima, I967-1972), p. 43; quoted in Assadourian, "La renta de la encomienda", p. I7I.

20. Conquest and mining were private initiatives. The Crown gave private entrepreneurs labour, land, and tributes to encourage them to engage in conquest and invest in technology. 21. Visita hecha a la provincia de Chucuito por Garci Diez de San Miguel en el año I567, palaeographic version by Waldemar Espinoza Soriano (Lima, 1964). 
Tribute demands under the Spanish amounted to an annual payment of I 8,000 pesos and I,000 items of clothing, plus various kinds of labour service. The Lupaqa organized themselves to collect the money and clothes. Part of the money was acquired through an allotment of mineworkers for Potosí (in I 567, for example, 500 workers were sent to the silver mine and, in I 578 - that is, after Toledo's reforms - 2,000 from almost I 5,000 domestic units). They also rented themselves and their animals for transport, sold llamas or wood, and worked as journeymen. Workers were paid for their labour in silver, with which they could pay all, or almost all, of the tribute to the Spanish.

They owed labour service to Spanish officials, including local governors, Church officials, and other local and regional elites. Labour was required for service in hostels for travellers, and building and maintenance of churches, providing the money and goods for religious festivals and holidays, and the workers carried out domestic work in the houses of the Spanish elite and tended their animals. According to witnesses of the royal inspection in Chucuito, during Inca times the subject indigenous people had to pay tribute mostly in labour and a few goods, though women and children were also in demand.

What then was the difference with the Spanish? As some indigenous authorities told the royal officers, the Spanish had no limits to their demands, although they had to negotiate with ethnic authorities, and they centred their desire on silver and textiles. The natives were also obliged to provide personal services, and not only to the royal authorities but to other Spaniards as well, for example to travellers.

At the time of the royal inspection in the late i 560 s, the concept of the New World as a territory based on its economic utility to the Crown became concrete policy. It identified the usefulness to Castile with what was fair for the indigenous people. The policy was put into action by the following two viceroys for Peru and New Spain: Francisco de Toledo and Martín Enriquez. ${ }^{22}$ The Crown asked for money ("money, money, coins, coins", said Enriquez) ${ }^{23}$ and that implied an emphasis on the production of silver and the greatest possible extension of forced labour systems.

The process took place simultaneously with the degradation of the power of religious orders. Toledo made a new assessment of the tribute, but the most important reforms were the reorganization of the indigenous population into repartimiento towns to facilitate a better administration of labour and tribute, and the organization of the mita system. In the early I 570 s the Church started to complain, but the necessity to the Crown of

22. Carlos Sempat Assadourian, "Acerca del cambio en la naturaleza del dominio sobre las Indias: la mita minera del Virrey Toledo, documentos de I568-1571”, Anuario de Estudios Americanos, 46 (1989), pp. 3-70.

23. Ibid., p. 6. 
the miners drowned out the clergy's voices. At the same time, the encomenderos began to lose their power, and after the reforms tributes were payable to the Crown. The encomienda system weakened in the Andes, and after several decades only other kinds of tribute remained.

\section{FREE AND UNFREE LABOUR IN POTOSÍ}

At the beginning of the exploitation of Potosí, the Spanish miners took advantage of native technology and knowledge, which was of course adapted to the extreme conditions of mining in the Andes. Almost all the mines were at high altitude, where there is very little, if any, combustible material. The native ovens used to smelt the ores used different kinds of local grasses, such as $i c h u$, a native form of hay that can be harvested every two years, or other vegetation, and during the first few decades Potosí was crowded with such ovens. The Spaniards also used the locals to look for mines, to extract and transport ores, and to carry out all the steps needed in processing the metals.

Until Toledo, labour organization was based on two kinds of worker: indios de encomienda and yanaconas. The first were subject to individual Spaniards, were obliged to pay them tribute in the form of services or goods, and worked at unskilled tasks in the mines; the latter also worked for the Spaniards as a kind of servant, working as specialized artisans in Potosí. Almost all processes, from the extraction of the minerals to the smelting of the metals, were performed by indigenous people.

In the early i 570 s production decreased at Potosí. The rich ores that had permitted traditional indigenous techniques to be used had already become scarcer by the i 560 s, but over the following decades a combined change in technology and better organization of the workforce led to a unique boom in silver production. On the technological side, the adaptation of a method of cold amalgam suitable for the quality of ores found in Potosí, the discovery of the Huancavelica mercury mine in Peru (Figure I), and the solving of various problems concerning those innovations, such as water management and the construction of mills for a different scale of production, allowed the mining centre to increase production to its highest level during colonial times (see Figure 3 below). The new technology did not completely replace the old methods, but it became dominant. The boom augmented the demand for workers, and it was against that background that Viceroy Francisco de Toledo organized the renewed mita system, based on an earlier indigenous institution. ${ }^{24}$

According to Murra, the mita during the Inca period entailed that a proportion of the domestic units in a community had to provide their labour for a fixed period, during which they had to carry out a range of

24. Cook, Demographic Collapse, especially ch. I2, "Mining and Population in the Central Sierra”. 
tasks such as repairing and building roads or bridges, tending the animals destined for public or religious use, working in the mines or in agriculture, and participating in military campaigns. ${ }^{25}$ Some local authorities too had the right to use labour from their own communities.

Viceroy Toledo adapted the idea of the mita system and organized an annual forced migration to Potosí during the I 570 . In 1578 it was decided that more than I 4,000 natives and their families would be required to work in the mines for a wage set below the market rate. Under the system, every year a proportion of the adult male native population from designated towns had to go to Potosí. They took their families with them and used the "wages" earned by all of them mostly to pay their adult male tribute obligations. The system served too as a method for Toledo to encourage Spanish entrepreneurs to invest in new technology in the course of the construction of the mills. They were given the mita workers, unskilled forced labourers who received a lower wage than free labourers, and in return the Spanish entrepreneurs had to build the mills, artificial lakes for water management, and the rest of the necessary infrastructure. The system was thought of as a temporary solution, but it lasted until independence $(\mathrm{I} 825) .{ }^{26}$

The new mining and metallurgical processes were rather complex and increased the necessity for the division of labour. Ore was extracted from mine galleries and taken to a location where labourers broke it up to facilitate its removal from the mine. Other workers were on hand to separate useful material from waste. ${ }^{27}$ All tasks except portering were performed by free workers. Llamas or mules were used to transport ore to the mills, where another gang of mitayos loaded it into the machinery. The next process, amalgamation, was then tackled by free labourers.

A description of Potosí from 1603 details part of the labour system. ${ }^{28}$ There were around 58,800 Indians working in Potosí (almost 20 per cent of the total indigenous population from Charcas and La Paz included in the Toledo inspection). Only 5, I00 of the total Indian labour force were mitayos, I0,500 were mingas (contracted workers), and 43,200 free wage earners. Although the mitayos numbered fewer than io per cent, they were important to the mining economy: they had to perform tasks that others did not want to do, and for a lower wage. ${ }^{29}$

25. Murra, “¿Existieron el tributo y los mercados?”, pp. 237-247.

26. Cole, The Potosi Mita, ch. I.

27. The description in Tandeter, Coacción y mercado, p. I6.

28. "Descripción de Potosí", in Silvio Zavala, El servicio personal de los indios en el Perú. Extractos del siglo XVII (Mexico City, I979), II, pp. I6-25.

29. The number of mita labourers is still being debated by scholars because there are few concrete sources, but also because many of the mitayos worked as free labourers during the weeks they had for rest. The figures taken from the 1603 description of Potosí are for discussion purposes only. 
Table I. Description of Potosi and its mines, $1603 .^{30}$

\begin{tabular}{llr}
\hline Indigenous people & Task & Numbers \\
\hline Repartimientos & Working in mines & 4,000 \\
Mingas & Being “rented" & 600 \\
Boys & Cleaning metal & 400 \\
& Looking for metal on the surface & 1,000 \\
Repartimientos & In processing mills & 600 \\
Mingas & In processing mills & 4,000 \\
Indigenous (men and & Working with llamas & 3,000 \\
$\quad$ women) & Transporting metals on llamas & 320 \\
Repartimientos & Looking for salt and bringing it to Potosí & 180 \\
Mingas & Bringing salt & 1,000 \\
Merchants & Selling wood & 1,000 \\
Indigenous (men and & Carrying fuel & 1,000 \\
$\quad$ women) & Carrying cocha (llama excrement) & 500 \\
Indigenous (men and & Gathering llama excrement, also used as a fuel & 200 \\
$\quad$ women) & Making and carrying coal & 1,000 \\
& Making candles & 200 \\
Total & Carrying food and other goods & 10,000 \\
\hline
\end{tabular}

Source: "Descripción de Potosí", in Zavala, El servicio personal de los indios en el Perú, II, pp. I6-25.

One of the worst jobs in the mines was removing the ore. The mitayos had to climb up and down in the mines using ladders, transporting 45 kilograms in each sack of ore at a quota rate of 25 sacks a day. Rodrigo de Loaisa, a Spanish cleric living in Potosí, noted in I 586: "If twenty healthy Indians enter on Monday, half may emerge crippled on Sunday". ${ }^{31}$ Some of the tasks fulfilled by the labourers were related in the above description of Potosí. This description included other workers in Potosí, apart from those working directly in mines or processing mills.

Table I shows the proportion of free and unfree labourers working in the mines and mills, and the general tasks performed by all the workers there. As we can see in Tables I and 2, workers comprised not only tributaries (men aged between eighteen and fifty) but also women and children, whose presence reinforces the idea that the indigenous people were working to earn the money to pay tribute and not only as "free labourers". That whole families worked in the mine implies, first, that tribute was not considered an individual obligation and, second, that it was difficult to fulfil, which meant that tributaries needed assistance.

30. In constructing this table I have retained the terminology of the original text.

31. Cook, Demographic Collapse, p. 238. 
Table 2. Other workers, Potosi i603.

\begin{tabular}{llc}
\hline Workers & Task & Numbers \\
\hline Women (indigenous) & Prostitution & "A large number" \\
Women (of a higher social status) & Prostitution & 120 \\
Women & Washing clothes & 100 "houses" \\
Men & Miners & "More than 100" \\
Indigenous & Herding llamas & 312 \\
\hline
\end{tabular}

Source: "Descripción de Potosí", in Zavala, El servicio personal de los indios en el Perú, II, p. 26.

Working in the mines of Potosí was just one component of the labour provided by the indigenous population. The journey started in their settlements, where all mitayos joined up to go to the mines. In I603 Alfonso Messia, a Spaniard who encountered such a group on his way to Potosí, described the impact of the Potosí mita on the inhabitants of Chucuito, where approximately 2,200 mitayos left each year, taking their wives and children with them. They had to travel 480 kilometres from the coast of Lake Titicaca to Potosí, which took them about two months:

I have twice seen them and can report that there must be 7,000 souls. Each Indian takes at least eight or ten llamas and a few alpacas to eat. On these they transport their food, maize and chuño [dried potatoes], sleeping rugs and straw pallets to protect them from the cold, which is severe, for they always sleep on the ground. All this cattle normally exceeds 30,000 head. [...] Only some two thousand people return: of the other five thousand some die and others stay at Potosí or the nearby valleys because they have no cattle for the return journey. ${ }^{32}$

Potosí was the unrivalled centre of the Spanish Empire in South America. Yet, there were a great many smaller mines, and one can suppose that the labour systems varied according to circumstances. How was the work organized in those mines where the mita did not exist? The case of San Antonio del Nuevo Mundo in the province of Lípez allows us to expand our view and to analyse free labour.

\section{SAN ANTONIO DEL NUEVO MUNDO: "FREE LABOUR"}

Lípez is situated in the southernmost Bolivian highlands, bordering the international frontier with Chile and Argentina to the west and south. South-east Lípez, which in the seventeenth century had a mining centre

32. Alfonso Messia, "Memorial sobre las cédulas de servicio personal de los indios (c.1600)", in Colección de documentos inéditos relativos al descubrimiento, conquista y colonización de las posesiones españolas en América y Oceania, VI (Madrid, I886), pp. I40-I42, quoted in Cook, Demographic Collapse, pp. 242-243. 
called San Antonio del Nuevo Mundo (Figure I), is too cold and dry for the development of any economically significant agriculture. This led to pastoral specialization and a strong tendency among its inhabitants to link up with farming communities from other regions, mainly but not exclusively through caravan traffic. Emphasis on herding results in smaller populations with dispersed settlement patterns and high seasonal mobility.

San Antonio del Nuevo Mundo is situated in the most hostile part of Lípez, the south-east, at 4,500 metres above sea level. In I602-1603, at the time of the first royal inspection, there was just a small population of herders living there, but eighty years later, during a new and important colonial inspection, almost all the population from Lípez, both north and south, were living in San Antonio. When asked why they had come to live there, those interviewed unfailingly answered that it was because their native towns were "sterile" and because this new place offered them better opportunities for work.

The mines of San Antonio were exploited only for a century, and occasionally later on, but on a smaller scale, and after its silver boom almost everybody went to live elsewhere. Historical research on this mining centre is still in progress and there is still very little known about its early days in the 1640 s. $^{33}$ However, we can be certain that in 1683 more than 2,000 indigenous people were working there at the time of the inspection.

There are at least two different kinds of source for the analysis of labour relations in the mine: the royal inspections, and legal records. There were two royal inspections related to San Antonio which inform us about the indigenous labour world, one in 1683 and the other in 1689. Based on their data, we can assert that many of the indigenous workers in the mines came from other regions, mostly from the Bolivian highlands (the "mita area" - see Figure 2). They transported salt, firewood, and ore. Almost all of them maintained links with their communities of origin and with the governor there, to whom they were still paying taxes. As an example, the following is one answer given by the Indians of Paria during the inspection of 1683 :

I asked them why they had left their provinces to come to this town, and how long they had been living here, and they answered that because their land was very sterile, providing no possibility to grow food to live on, nor pastures for their animals, and that is the reason why they have moved to this settlement to work in the mines and mineral refinery of this area and to others to carry metals, firewood, and salt to refine the metals, and it has been for twenty years that 


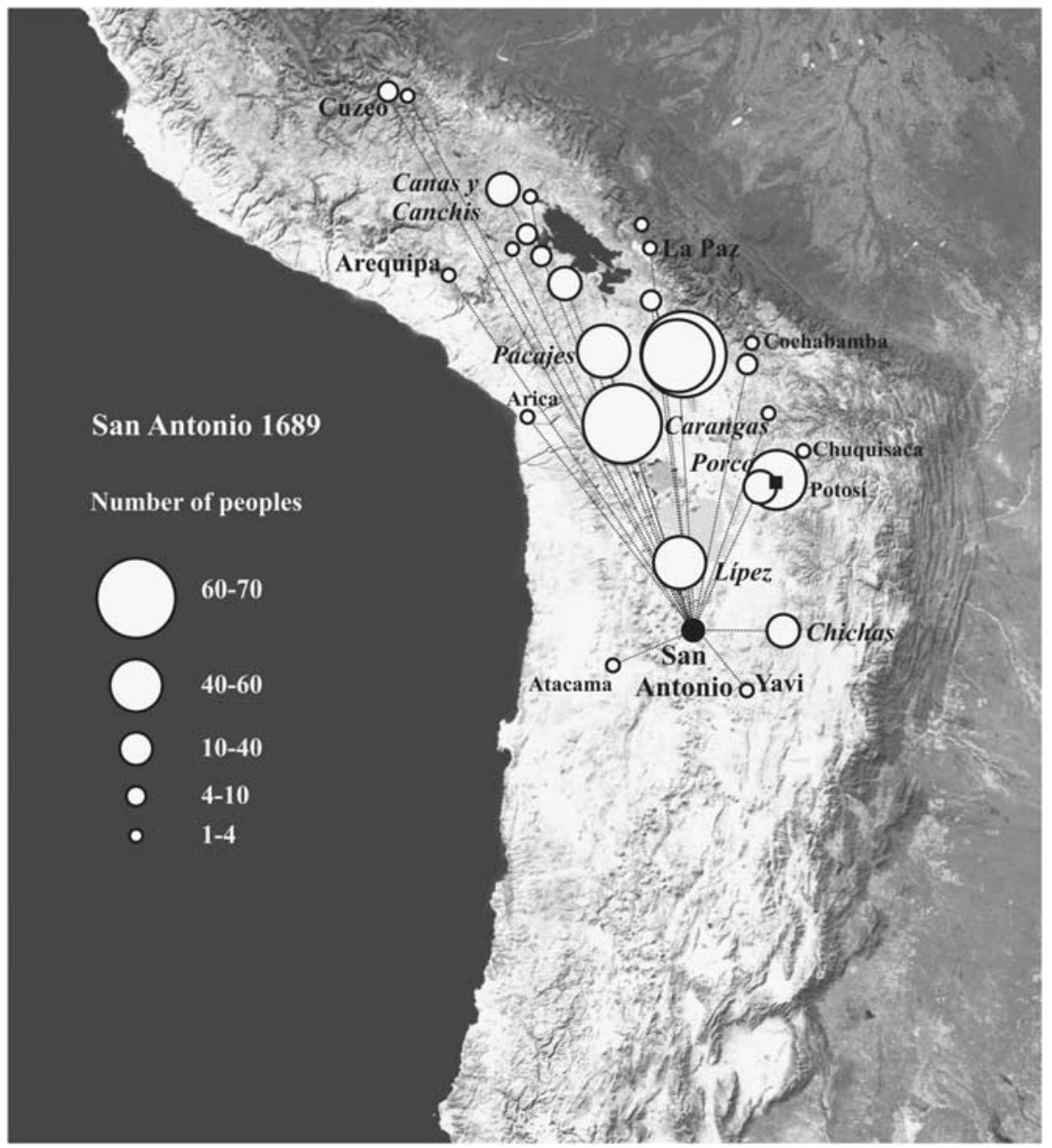

Figure 2. Indigenous migrants working in San Antonio del Nuevo Mundo in I689. NASA. Population source: AGN I3-23-I0-2

some of them live in this province, and others for the last eight years, and that they pay taxes to their curacas [ethnic authorities] and that they all belong to the Potosí mita where they pay in cash or in labour. ${ }^{34}$

The royal inspection shows that an important part of the indigenous mining population came from different places, some of them very distant. They were not mitayos: in theory they went to work there voluntarily.

34. Archivo General de la Nación Argentina [hereafter, AGN], Sala I3-18-6-5, Padrones de Potosí I602-I683. 
The inspection of 1683 focused on the mines; the second one, of 1689 , provides us with a more complete picture of the region, since it takes into account the many other herders living nearby. ${ }^{35}$ Both inspections point to a variegated indigenous population working the mines, stemming from different communities and trying to earn money.

Through the information provided by those sources we can grasp some aspects of the mining setting. The migrants went to San Antonio mostly with their families, and they stayed there many years. The majority were herders, since animals were used daily in all stages of the production process and to supply the town and mines. A few of them were muleteers from the Atacama Desert who came with goods and stayed there, or continued to work in transport. Mules were very expensive to feed in San Antonio, because of the poor grass and the extra food needed. The majority of the pack animals were llamas, and their herders were natives from many places in the highlands, including north Lípez. Llama herders were crucially important to this very high mine, with no agriculture and no vehicles.

In those years, the population of Lípez was living around the mining complex in the south-east and had virtually abandoned its old settlements to the north. Indigenous labourers were used directly in the mines as miners, and for transporting ore from the mines to the mills; then, more of them began actually to work in the mills. More still acted as porters, carrying food and everything else needed to survive and work at so great an altitude.

Legal records show a more heterogeneous population living in San Antonio. During the century when the mine was functioning, a town was constructed, and later a township closer to the mines, inhabited by people who wanted to take advantage of its location. In the township one might have encountered both Spaniards and mestizos trading in stolen silver, and others running illegal mills. There were general stores where indigenous people sold stolen tools in exchange for wine or other goods. ${ }^{36}$ Slaves from Angola and the Congo were sold, owners being Spanish or Indian. ${ }^{37}$ A flourishing economic life developed around the mines, and it attracted all sorts of labourers, and not only natives.

In a schematic synthesis we can conclude that many of the owners of mines and mills were Spanish, and so were some of the specialists, such as carpenters from Potosí who came to build the galleries, mercury traders, colonial authorities, and merchants. The natives on the other hand worked mostly in mines, mills, transport, in providing food to the miners,

35. Raquel Gil Montero, "Los pastores frente a la minería colonial temprana: Lípez en el siglo XVII", in Lautaro Nuñez and Axel Nielsen (eds), Viajeros en ruta: arqueología, historia y etnografía del tráfico Surandino (forthcoming).

36. Archivo y Bibliotecas Nacionales de Bolivia [hereafter, ABNB], Minas 59, San Antonio del Nuevo Mundo, I686/1687.

37. ABNB, Escrituras Públicas, Tomo I37, fo. 104. 
and in herding animals. Slaves were not really important in terms of numbers, and I have been unable to find any description of their duties.

For about a century, San Antonio was a mining centre created around important silver veins. During that time, in a territory 4,500 metres above sea level that had scarcely been inhabited before, thousands of labourers arrived and settled. Some came from very distant places, with their animals, and lived around the mines, in or near the town of San Antonio. There was no mita system in Lípez. Many of the migrants declared that they were mitayos, that they had previously worked under the Potosí mita system, or had worked for payment in silver. The silver they earned was necessary to pay tribute and other colonial obligations.

\section{DISCUSSION}

Enrique Tandeter shares Platt's view, cited at the beginning of this essay, that the mita was a colonial pact in which indigenous people played a significant role and had some scope to negotiate. However, this analysis focuses on a period during which the mita was different from that organized by Toledo. Although the number of mitayos decreased during that time, their proportion in relation to the total number of labourers rose. At the end of the colonial period, nearly half the labourers in Potosí were mitayos and the rest were free. As noted earlier, at the beginning of the seventeenth century about Io per cent of workers were mitayos. ${ }^{38}$ The mita system was much more important at times when production at Potosí was less profitable.

In many respects, the mita system changed over time, and the differences are important for analysing labour relations during the sixteenth and seventeenth centuries. Initially, Toledo granted mining entrepreneurs an allocation of a "labour rent". ${ }^{39}$ Other than in the case of the Lupaqa people mentioned before, the individual colonialist entrepreneurs, not the representatives of the Spanish state, collected that rent as money or in kind. From the very beginning it was possible for the mitayo to fulfil his obligation in silver.

At first, Toledo allotted mining entrepreneurs a number of labourers for unskilled tasks and at low wages. They were a stimulus to the important investments needed for the changes required by the new amalgam technology. In time, and with the departure of so many mitayos, the possibility of fulfilling obligations in silver became more common, enabling an entrepreneur to pay other workers and replace the ever-increasing number of absentees. In the course of the second half of the seventeenth century, many

38. This proportion is difficult to determine exactly; it is more a case of what the documents suggest. There are no statistics.

39. Tandeter, Coacción y mercado, p. I8. 
mining entrepreneurs made use of that possibility, which was sometimes considered more profitable than actually running the mines. Nonetheless, it did not become a general phenomenon and remained merely another way to oblige indigenous people to earn money.

The mita system has a further implication: in comparison with the old indigenous methods, the new system of amalgam-forming increased the need for a division of labour. Under the new system the mitayos performed the hardest and least specialized tasks for less money. So what was the difference between working in a mine to fulfil an obligation and working as a mitayo? Simply this: a free labourer could earn more money than a mitayo, and could obtain better paid work down the mines.

The mita system changed in quantitative terms too. In I 578, the fixed total of migrants was $\mathrm{I} 4, \mathrm{I} 8 \mathrm{I}$; in $\mathrm{I} 633, \mathrm{I} 2,354$; in $1688,5,658$; and in 1692 , 4 , IOI. It is safe to assume that the reduction was a direct consequence of demographic decline. Between the two royal inspections, the first ordered by Viceroy Francisco de Toledo (I 573) and the second by Viceroy Duke De La Palata (I683), the indigenous population of the highlands diminished by 45 per cent and migration increased. However, production at Potosí and the demand for labour also decreased strongly during the seventeenth century, while the mita allocation kept pace with production (see Figure 3 below).

The royal inspections and the collection of tributes in Potosí showed changes over time between different categories of tributary. The best known is the increase in migrants. Moreover, the number of indios de encomiendas decreased and that of yanaconas (that is, labourers separated from their communities and considered by many authors as servants of a kind) increased. A number of yanaconas had worked in Potosí right from the very beginning, as specialized artisans.

One finding of the royal inspection ordered by La Palata in $\mathrm{I} 683$ is that in the province of Charcas almost half the indigenous people present were migrants. ${ }^{\circ}$ The traditional explanation for the increase was that many left their communities to try to avoid the mita. ${ }^{4 \mathrm{I}}$ However, recent research

40. Nicolás Sanchez de Albornoz, Indios y tributos en el Alto Perú (Lima, I978), p. 49.

4I. The bibliography on these migrants is large. The first general study was that by Sanchez de Albornoz, Indios y tributos en el Alto Perú. During the next decade, several new interpretations contributed to a better understanding of the forasteros: Carlos Sempat Assadourian, "La organización económica espacial del sistema colonial", in idem, El sistema de la economía colonial. El mercado interior, regiones y espacio económico (Mexico City, 1983), pp. 255-306; Thierry Saignes, "Ayllus, mercado y coacción colonial: el reto de las migraciones internas en Charcas (siglo XVII)", in Olivia Harris, Brooke Larson, and Enrique Tandeter (eds), La participación indigena en los Mercados Surandinos. Estrategias y reproducción social. Siglos XVI al $X X$ (La Paz, 1987), pp. I I I-I 58; and Thierry Saignes, "Políticas étnicas en la Bolivia colonial. Siglos XVI-XIX", in Indianidad, etnocidio e indigenismo en América Latina (Mexico City, I988), pp. 4I-77. During the royal inspection of La Palata the authorities and the Viceroy himself thought that the forasteros wanted to avoid mita and tributes. 


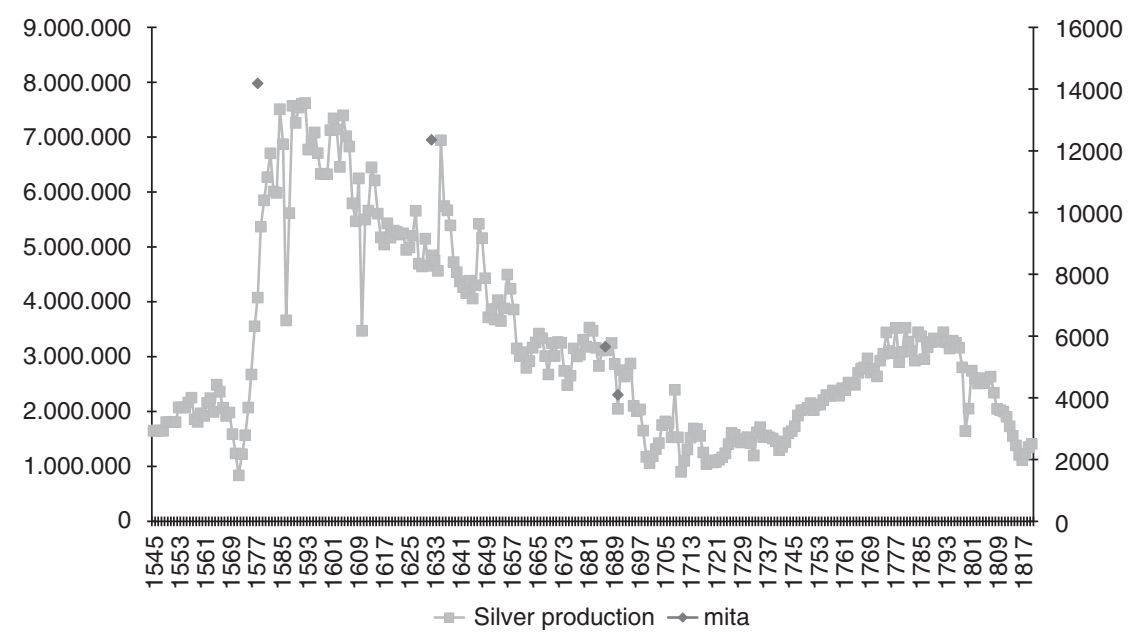

Figure 3. Silver production in Potosí (in pesos), I 545-1823, and mita allocations.

Silver production dataset in Richard Garner, Economic History Data Desk: Economic History of Latin America, United State and New World, I500-1900, downloaded from https:// home.comcast.net/ richardgarneros/tepaske.html. The mita allocation is taken from Tandeter, Coacción y mercado, pp. 39 and 40.

shows that many migrants were working in different mines (following their discovery, and the silver boom), and that they were paying tribute and paying for the cost of their replacement under the mita, at least during the seventeenth century. ${ }^{42}$ Mitayos and yanaconas were migrants, but there were also "free" indigenous migrants.

The term "migrant" included anyone who moved in search of work or to trade in the camps, but mitayos and yanaconas theoretically moved with the knowledge and on the orders of the Spanish Crown or of individual mining entrepreneurs, although other workers could migrate without official permission. During the seventeenth century people migrated chiefly because of colonial obligations, and most of them moved to the mines. Migration decreased in the eighteenth century.

After the Toledo reforms, the tribute of the yanacona was valued and they, or their landlords, were then obliged to pay it. The series of records of their payments, however, is incomplete: we have information for the periods I 574-1604 and I660-1690. Taking into account only those years for which data exist, the yanacona were fewer than io per cent of all those obliged to pay tribute in the second half of the sixteenth century and

42. Ann Zulawsky, "Forasteros y yanaconas: la mano de obra de un centro minero en el siglo XVII", in Harris, Larson, and Tandeter, La participación indigena, pp. I s9ér92; Gil Montero, "Los pastores frente a la minería colonial temprana". 
around 40 per cent in the second half of the seventeenth century. We can also regard the yanaconas who worked in the mining cities and paid tribute to the Crown after the Toledo reforms as "free labourers", similar to other tributaries who migrated to Potosí.

What can be proposed then on the basis of this information? According to the scholars previously quoted, during the early decades of the colonial period we observe an important change: encomenderos and other conquerors made people work for them without limits in almost all productive tasks - agriculture, construction, mining, and transport. The natives had to give them their labour "tribute" as part of an encomienda, and in Potosí specifically they worked mostly at unskilled tasks. There were also other labourers, the yanaconas, specialized servants who, while they worked for the Spanish, did so as skilled artisans at Potosí. The discussion of the nature of this tribute is still open: did the natives also have to give goods to the Spaniards? For Murra, that signifies an important difference: during Inca times the natives had to work for the conquerors, or to deliver both men and women to them, which was later interpreted as reciprocal labour, and not as tribute. ${ }^{43}$

An important change in relations between conquerors and subjects was the assignment of value to the tribute, which implied that the natives had to pay certain allocations of silver, or pesos, and some goods. They had other obligations too, such as personal services, to the Church, to civil authorities, and to Spanish travellers, to which can be added the mita, which was more complex than its Potosí counterpart. The "conversion" of tribute and mita into money induced the indigenous people to embark upon commercial activity in their attempts to obtain the means to pay tribute. The information contained in the royal inspection of San Antonio is very clear in this respect: all migrants went there to work, because there they could find a job to pay for their clothes, food, and their obligations. ${ }^{44}$ Their statements show that working in the mines was not really voluntary. People from northern Lípez claimed that:

[...] almost all men and women, and boys and girls, from this village of San Agustín de Chuica are working in San Antonio de Lípez, and in other places of this province, under the charge of different persons, some Spanish, some indigenous, and although they [native local authorities] insisted [to the owners of the mines] that those workers [indigenous tributaries] be allowed to come to the village during the inspection, they do not even come to the religious feasts that are in this month, and the curacas [native authorities] were offended when they tried to bring them out of San Antonio. ${ }^{45}$

There were also two important differences in mining tasks and organization in the period before and after Toledo's reforms. On the one hand, 
in Potosí the use of traditional technology allowed the natives to participate in all mining processes, whereas later, the amalgam method put the organization of the processes into the hands of the entrepreneurs, so that native people lost their agency. On the other hand, the organization of the mita system coincided with the end of the encomiendas. Although mining was a private enterprise, with the organization of the mita the Spanish Crown had the power to organize and distribute forced labour among the mines.

Moreover, it is essential to take the differing contexts into account. During the Toledo reforms, but especially afterwards, the indigenous population diminished significantly for many reasons, including conquest, wars, epidemics, the demands of the work, and migration. A relatively small number of Spaniards managed to conquer a huge territory, often with the support of indigenous authorities as important allies. Those authorities negotiated with the conquerors and were in a way the beneficiaries of many of the changes, and responsible for procuring tribute. Some indigenous societies participating in the mita system were stratified, such as the Lupaqa, and their authorities exerted considerable influence on their people. The links between many authorities and their subjects were strong and explain why the tribute system and the mita were honoured even when the subjects were far from their communities.

\section{CONCLUSION}

Although it is still difficult to state it with certainty, it seems that the changes to the labour system implied a rupture of community links, hence the increased numbers of yanacona servants, but also of migrants who changed their tributary status. There was an increased proportion of forced workers in the mines, because of the drop in production, a shift from personal services to tribute, and a better situation for indigenous negotiation, for by then people had more knowledge about the colonial system, and the Crown was more heavily dependent on tribute. That was the historical context that the people of Potosí were referring to when they recalled their past as mitayos in the late twentieth century - and which Platt described so vividly in the lines cited at the beginning of this essay.

During early colonial times, and principally in the first few decades, many indigenous people, not only the mitayos, were obliged to work in the mines. The need for labourers, especially after the Toledo reforms and the silver boom, implied that the colonial authorities were concerned with the organization of the labour market, but after the silver crisis fewer labourers were needed. All the changes occurred in a context of a steep decrease in the size of the population during the sixteenth and seventeenth centuries, and its recovery after the last epidemic in 1720 .

Mining was also an opportunity for individuals to earn more money to fulfil their colonial obligations. For the mitayos it was more rewarding to 
pay for a replacement than to work in the mines. Contrary to the opinions of some viceroys, the majority of the indigenous people usually migrated precisely because of their obligations and not because they wished to avoid them. Speaking about "free labour" in a context of tribute, then, means only the possibility of choosing the place and the tasks to perform there, but is not really equivalent to any modern concept of a labour market.

The institution of the mita changed over the years and the concept varied with respect to unfree labour and tribute relations. A closer analysis of historical labour relations allows us to distinguish such faint traces. Considered in the long run, the era of the Toledo reforms in the I 570 s, and the subsequent century, were the worst periods in terms of pressure on, and extraction from, the native population. 